\section{BUTTERFLIES OF MADURAI CITY, TAMIL NADU}

\author{
S. Baskaran and A. Solaiappan \\ Post-graduate and Research Department of Zoology, Ayya Nadar \\ Janaki Ammal College, Sivakasi, Tamil Nadu 626124, India.
}

Madurai $\left(9^{0} 37^{\prime}-10^{\circ} 11^{\prime} \mathrm{N} \& 77^{0} 26^{\prime}-78^{\circ} 40^{\prime} \mathrm{E}\right)$ is situated at $101 \mathrm{~m}$ and covers $22 \mathrm{~km}^{2}$ area. The average rainfall of the region is $85 \mathrm{~cm}$. Mam-made park, riverine, urban and open land are the four distinct habitats of the study area.

The study was carried out for nine months from August 2000 to April 2001. The butterflies were observed between 0800 hours and $1400 \mathrm{hr}$ and were identified following Wynter-Blyth (1957) and Varshney (1997). A list of butterflies found in different habitats is given in Table 1 .

Altogether 33 species of butterflies belonging to seven families (Tables 1 \& 2) have been recorded from Madurai City. Among the families, Nymphalidae was found to be dominant followed by Pieridae, Papilionidae, Lycaenidae and Danaidae.

The parks were found to have plants like Hibiscus rosasinensis, Tridax procumbens, Pongamia pinnata, Tamarindus indicus, Cynodon dactylon and Gardenia resinifera etc.

River Vaigai flows through Madurai. The vegetation found along the banks of Vaigai includes Calotropis gigantea, Ficus hispida, Azadirachta indica, Tridax procumbens, Cocos nucifera, Jatropa spp., Leucas aspera, Dalbergia sp. and Terminalia spp.

In the urban layout, the housing areas of Doak Nagar, Anna Nagar, H.M.S. Colony, KK. Nagar, Chokkikulam, Pykara, Duraisamy Nagar, S.S. Colony and Railway colony were studied. The vegetation found on the streets, and grown in houses included Hibiscus rosasinensis, Pongamia pinnata, Citrus limon, Jasminum officinalis, Lycopersicon esculentum and Crotalaria spp.

To study the openland habitat, lands left for construction, road side lands and some of the cultivated lands were visited. The vegetation of this area includes Caesalpinia spp., Calotropis gigantea, Cocos nucifera, Acacia spp., Ficus religiosa, Azadirachta indica, Tridax procumbens, Jatropa glandulifera, Leucas aspera, Oryza sativa, Ixora coccinia and Tribulus
Table 1. Systematic list of butterflies of Madurai City.

\begin{tabular}{|c|c|}
\hline Common name & Scientific name \\
\hline \multicolumn{2}{|l|}{ Danaidae } \\
\hline Striped Tiger & Danaus genutia \\
\hline Dark Blue Tiger & Tirumala septentrionis \\
\hline Plain Tiger & Danaus chrysippus chrysippus \\
\hline Common Crow & Euploea core core \\
\hline Blue tiger & Danaus limniace leopardus \\
\hline \multicolumn{2}{|l|}{ Acraeidae } \\
\hline Tawny Coster & Acraea violae \\
\hline \multicolumn{2}{|l|}{ Satyridae } \\
\hline 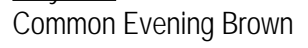 & Melanitis leda leda \\
\hline \multicolumn{2}{|l|}{ Lycaenidae } \\
\hline Zebra Blue & Syntarucus plinius \\
\hline Common Cerulean & Jamides celeno celeno \\
\hline Indian Cupid & Everes lacturnus \\
\hline Pale Grass Blue & Zizeeria maha ossa \\
\hline Plain Cupid & Euchrysops pandava \\
\hline \multicolumn{2}{|l|}{ Pieridae } \\
\hline 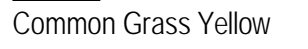 & Terias hecabe \\
\hline Common Jezebel & Delias eucharis \\
\hline Lemon Emigrant & Catopsilia pomona f. florella \\
\hline Mottled Emigrant & Catopsilia pyranthe \\
\hline Psyche & Leptosia nina nina \\
\hline The Crimson Tip & Colotis danae \\
\hline \multicolumn{2}{|l|}{ Papilionidae } \\
\hline Common Blue Bottle & Graphium sarpedon teredon \\
\hline Tailed Jay & Graphium agamemnon menides \\
\hline Common Mormon & Papilio polytes polytes \\
\hline Common Mormon & Papilio polytes romulus \\
\hline Common rose & Pachilopta aristolochiae \\
\hline Lime Butterfly & Papilio demoleus \\
\hline \multicolumn{2}{|l|}{ Nymphalidae } \\
\hline Blue Pansy & Junonia orythia \\
\hline Chocolate Pansy & Junonia iphita iphita \\
\hline Common Castor & Ergolis morione \\
\hline Danaid Egg fly & Hypolimnas misippus \\
\hline Great Egg fly & Hypolimnas bolina \\
\hline Lemon Pansy & Junonialemonias \\
\hline Peacock Pansy & Junonia almana \\
\hline Yellow Pansy & Junonia hierta \\
\hline Common Leopard & Phalanta phalantha phalantha \\
\hline Common Sailer & Neptis hylas varmona \\
\hline
\end{tabular}


Table 2. Relative abundance of butterfly families in Madurai City.

\begin{tabular}{ll}
\hline Family & $\begin{array}{l}\text { No. of species and relative } \\
\text { abundance }\end{array}$ \\
\hline Danaidae & $5(15.15 \%)$ \\
Acraeidae & $1(3.03 \%)$ \\
Satyridae & $1(3.03 \%)$ \\
Lycaenidae & $5(15.15 \%)$ \\
Pieridae & $6(18.18 \%)$ \\
Papilionidae & $5(15.15 \%)$ \\
Nymphalidae & $10(30.31 \%)$ \\
Total & 33 \\
\hline
\end{tabular}

terrestris.

\section{References}

Varshney, R.K. (1997). Revised nomenclature for taxa in WynterBlyth's book on the butterflies of Indian region. Journal of the Bombay Natural History Society 76(1): 33-40.

Wynter-Blyth, M.A. (1957). Butterflies of Indian Region Bombay Natural History Society Publication, Bombay, 523pp.+72pls.

\section{ADDITIONS TO THE ODONATA (INSECTA) OF THIRUVANANTHAPURAM DISTRICT, KERALA}

\author{
K.G. Emiliyamma and C. Radhakrishnan \\ Western Ghats Field Research Station, Zoological Survey of India, \\ Kozhikode, Kerala 673002, India.
}

Peters (1981) reported 26 species of Odonata from Thiruvananthapuram District of Kerala State, southern India. The present study is based on the Odonata collections made from this district, during the faunistic surveys conducted by Zoological Survey of India (Western Ghats Field Research Station, Calicut and Southern Regional Station, Chennai) in 1997, 1998 and 2001. As a result of these surveys, 27 species and subspecies of Odonata belonging to 17 genera and seven families could be collected and identified. Of these, 17 species and subspecies are new additions to the Odonata fauna of Thiruvananthapuram District. Accordingly, till date a total of 43 species and subspecies of Odonata are known from this district. A systematic list of all the 43 species recorded from the district and a systematic account of the species collected during the current surveys are provided below. The specimens studied are deposited in the faunal depository of the Zooligcal Survey of India, Kozhikode.

The nomenclature followed here is after Fraser $(1933,1934,1936)$ and Tyagi (1997).

Systematic list

Order: Odonata

Suborder: Zygoptera

Superfamily: Coenagrionoidea

Coenagrionidae

1. * Aciagrion occidentale Laidlaw

2. Agriocnemis keralensis Peters

3. Agriocnemis pygmaea (Rambur)

4. Agriocnemis splendidissima Laidlaw

5. Ceriagrion cerinorubellum (Brauer)

6. Ceriagrion coromandelianum (Fabricius)

7. * Ischnura aurora aurora Brauer

8. * Ischnura senegalensis (Rambur)

9. Mortonagrion varralli Fraser

Manuscript received 16 February 2002

Accepted for publication 12 August 2002 